\title{
The age of developing diabetes and FTO polymorphisms (rs9939609, rs1421085, and rs9930506)
}

\author{
Wiek w momencie ujawnienia się cukrzycy a polimorfizmy genu FTO \\ (rs9939609, rs1421085 i rs9930506)
}

\section{Władysław Grzeszczak', Maciej Molsa' ${ }^{1}$, Marek Tłuczykont' ${ }^{1}$ Anna Markowicz' ${ }^{1}$, Ryszard Swoboda ${ }^{1}$, Marta Biedak', Anna Kałuża', Sebastian Sirek ${ }^{1}$, Krzysztof Strojek ${ }^{2}$}

${ }^{1}$ Department of Internal Medicine, Diabetology and Nephrology in Zabrze, Medical University of Silesia in Katowice ${ }^{2}$ Department of Internal Diseases, Diabetology and Cardiometabolic Diseases, SMDZ in Zabrze, Medical University of Silesia in Katowice, Silesian Center for Heart Diseases, Zabrze, Poland

\begin{abstract}
Introduction: Type 2 diabetes (T2DM) is a common complex metabolic disorder that has a strong genetic predisposition. Fat mass and obesity-associated protein (FTO) is one of the genes of interest to us. Hypomethylation of a CpG site in the FTO gene was significantly associated with the risk of T2DM. The aim of the study was to find the answer to the question of whether the polymorphism changes of the FTO gene in the pathogenesis of type 2 diabetes are comparable in young, middle aged, and elderly people.

Material and methods: The study involved 282 consecutive patients with type 2 diabetes, who attended a primary healthcare clinic in Southern Poland. The study subjects were divided into three groups according to the age at which type 2 diabetes mellitus was diagnosed (> 40 years old, 40-60 years old, and > 60 years old). The genotyping of rs9939609, rs1421085, and rs9930506 FTO polymorphisms was conducted using TaqManPre-designed SNP Genotyping Assay.

Results: No statistically significant difference was shown between the examined FTO polymorphism (rs9939609, rs1421085, and rs9930506) distribution between the subjects diagnosed with diabetes $<40$ years , 40-60 years, and $>60$ years old.

Conclusions: There were no statistically significant relationships between the different analysed anthropometric and other parameters and distribution of examined FTO polymorphisms (rs9939609, rs1421085, and rs9930506). The age of diabetes was not affect by the tested FTO polymorphisms (rs9939609, rs1421085, and rs9930506). (Endokrynol Pol 2017; 68 (4): 402-406)
\end{abstract}

Key words: diabetes type 2; FTO gene; age

\section{Streszczenie}

Wstęp: Cukrzyca typu 2 (T2DM, type 2 diabetes) jest często występującym złożonym zaburzeniem metabolicznym o silnych uwarunkowaniach genetycznych. Jednym z genów budzących zainteresowanie badaczy jest gen FTO (fat mass and obesity-associated gene). Hipometylacja w pozycji CpG genu FTO wiązała się istotnie z ryzykiem rozwoju T2DM. Celem badania było znalezienie odpowiedzi na pytanie, czy polimorfizmy genu FTO w patogenezie cukrzycy typu 2 są podobne u osób w młodym, średnim i podeszłym wieku.

Materiały i metody: Do badania włączono 282 kolejnych chorych na cukrzycę typu 2, którzy zgłaszali się do placówki podstawowej opieki zdrowotnej w Polsce południowej. Uczestników badania podzielono na trzy grupy w zależności od wieku w momencie rozpoznania cukrzycy typu 2 (> 40 lat, 40-60 lat i > 60 lat). Przeprowadzono genotypowania polimorfizmów rs9939609, rs1421085 i rs9930506 genu FTO, używając zestawu TaqMan do genotypowania SNP.

Wyniki: Nie wykazano statystycznie istotnych różnic w rozkładzie badanych polimorfizmów genu FTO (rs9939609, rs1421085 i rs9930506) między osobami, które w momencie rozpoznania cukrzycy miały < 40 lat, 40-60 lat lub $>60$ lat.

Wnioski: Nie stwierdzono statystycznie istotnych związków między różnymi analizowanymi parametrami (np. parametrami antropometrycznymi) a rozkładem badanych polimorfizmów genu FTO (rs9939609, rs1421085 i rs9930506). Oceniane polimorfizmy genu FTO (rs9939609, rs1421085 i rs9930506) nie wpływały na wiek chorych w momencie rozpoznania cukrzycy. (Endokrynol Pol 2017; 68 (4): 402-406)

Słowa kluczowe: cukrzyca typu 2; gen FTO; wiek

\section{Introduction}

According to the International Diabetes Federation's Diabetes Atlas sixth edition, it was estimated that 382 million people had diabetes in the year 2013 worldwide, and this figure is expected to increase to 592 million in 2035 [1]. In 2014, 4.9 million deaths were attributable to diabetes. It is also the leading cause of blindness, chronic kidney disease, and amputation. A substantial effort to understand the pathophysiology of type 2 diabetes (T2DM) and to develop novel preventive and therapeutic measures for T2DM has been made in recent years [2].

Type 2 diabetes (T2DM) is a common complex metabolic disorder that has a strong genetic predisposition. 
During the past decade, progress in genetic association studies has enabled the identification of at least 75 independent genetic loci for T2DM, thus allowing a better understanding of the genetic architecture of T2DM [2]. Among genes we thing about of TCF7L2, PPARG, KCNJ11 and FTO, and identified novel loci for an association in the intergenic region [3-5].

Fat mass and obesity-associated protein (FTO) is one of the genes of interest to us. Hypomethylation of a $\mathrm{CpG}$ site in the FTO gene was significantly associated with the risk of T2DM [6]. Fat mass and obesity-associated protein, also known as alpha-ketoglutarate-dependent dioxygenase (FTO), is an enzyme that in humans is encoded by the FTO gene located on chromosome 16 . As one homolog in the AlkB family of proteins, it is the first mRNA demethylase to be identified. The FTO gene is widely expressed in both foetal and adult tissues. This gene is a nuclear protein of the AlkB-related non-haem iron and 2-oxoglutarate-dependent oxygenase superfamily, but the exact physiological function of this gene is not known. Other non-heme iron enzymes function to reverse alkylated DNA and RNA damage by oxidative demethylation. Studies in mice and humans indicate a role in nervous and cardiovascular systems and a strong association with body mass index, obesity risk, and type 2 diabetes. The presence of the FTO rs9939609 A allele was found to be positively correlated with symptoms of metabolic syndrome, including higher fasting insulin, glucose, and triglycerides, and lower HDL cholesterol. The researchers identified 10 different FTO SNPs in the first intron of the gene, which associated with both BMI and type- 2 diabetes.

The development of type 2 diabetes occurs at different ages. In some patients the disease develops at a young age, in some middle age, and in some over 60 years old. In the pathogenesis of diabetes participate environmental as well as genetic factors. It has previously been shown that the polymorphisms in the gene FTO play an important role in the development of diabetes. An interesting seem to find an answer to the question of whether the genetic effect is the same in the young and in the elderly.

\section{Aim}

The aim of the study was to find the answer to the question of whether the polymorphism changes of the FTO gene in the pathogenesis of type 2 diabetes are comparable in young, middle aged, and elderly people. To find the answer to the above questions we estimated three FTO polymorphisms located in the first intron of this gene in people diagnosed with type 2 diabetes in age $<40$ years, between 40 and 60 years, and $>60$ years.

\section{Material and methods}

The study involved 282 consecutive patients with type 2 diabetes, who attended a primary healthcare clinic in Southern Poland. Study subjects were divided into three groups according to the age at which type 2 diabetes mellitus was diagnosed ( $>40$ years old, 40-60 years old, and $>60$ years old). The genotyping of rs9939609, rs1421085, and rs9930506 FTO polymorphisms was conducted with fluorescent-labelled probes using predesigned single nucleotide polymorphisms assessment sets (TaqManPre-designed SNP Genotyping Assay, Applied Biosystems). The distribution of the abovementioned polymorphisms are in Hardy-Weinberg equilibrium [7].

\section{Statistical analysis}

The data obtained were presented as mean \pm standard deviation. Normality of data distribution was tested with the Shapiro-Wilk test. In the case of non-normal distribution, data were normalised with logarithmic transformation. Analysis of variances with Tukey posthoc test and t-Student test were used in groups for mean comparison. Homogeneity of variances was tested with the Levene test. Correlations were calculated with the Spearman correlation coefficient. All calculations were performed with Statistica 9.0 software, and $\mathrm{p}<0.05$ was set as statistically significant.

\section{Results}

All patients were divided into three groups. Table I presents the main results conducted among subjects.

In the analysed group patients differed in the age of diagnosis of diabetes, and diabetes duration. In subjects with diabetes diagnosed and BMI > 60 it was significantly lower than in the other groups. It was also shown that subjects with diabetes diagnosed at $>60$ years old significantly less frequently used insulin than people in the other groups, and significantly more often used oral treatment than those with diabetes diagnose at age 40-60 years. A similar analysis was performed for subjects who were carriers of all kinds of FTO polymorphisms. There were no significant differences between these groups.

Tables II A, B, show the results of determinations of FTO polymorphisms rs9939609, rs1421085, and rs9930506.

No statistically significant difference was shown between the examined FTO polymorphism (rs9939609, rs1421085, and rs9930506) distribution between the subjects with diabetes diagnosed at $<40,40-60$, and $>60$ years.

There were no statistically significant relationships between the different analysed anthropometric 
Table I. Basic results obtained in the subjects after the division depending on the age of diagnosis of diabetes Tabela I. Podstawowe wyniki w zależności od wieku chorych w momencie rozpoznania cukrzycy

\begin{tabular}{|c|c|c|c|c|}
\hline & $\begin{array}{l}\text { Diabetes diagnosis } \\
\text { at }<40 \text { years old } \\
\text { A }\end{array}$ & $\begin{array}{l}\text { Diabetes diagnosis } \\
\text { at } 40-60 \text { years old } \\
\text { B }\end{array}$ & $\begin{array}{l}\text { Diabetes diagnosis } \\
\text { at }>60 \text { years old } \\
\text { C }\end{array}$ & Statistical significance \\
\hline $\mathrm{N}$ & 82 & 100 & 100 & \\
\hline Age [years] & $54.2 \pm 11.5$ & $62.5 \pm 8.6$ & $73.8 \pm 7.3$ & $\mathrm{p}<0.05$ between each group \\
\hline $\begin{array}{l}\text { Age at diagnosis of diabetes } \\
\text { [years] }\end{array}$ & $36.9 \pm 4.5$ & $51.0 \pm 4.7$ & $67.5 \pm 6.1$ & $p<0.05$ between each group \\
\hline \multirow[t]{2}{*}{ Duration of diabetes [years] } & $17.4 \pm 11.0$ & $11.6 \pm 8.0$ & $6.3 \pm 5.6$ & \\
\hline & & & & $p<0.05$ between each group \\
\hline BMI $\left[\mathrm{kg} / \mathrm{m}^{2}\right]$ & $31.5 \pm 5.2$ & $30.7 \pm 5.0$ & $29.0 \pm 4.4$ & $p<0.05$ between groups $C$ and $A$ and $B$ \\
\hline Hypertension [\%] & $59(72 \%)$ & $75(75 \%)$ & $74(74 \%)$ & NS \\
\hline Dyslipidaemia [\%] & $39(48 \%)$ & $61(61 \%)$ & $56(56 \%)$ & NS \\
\hline Oral hypoglycaemic drugs [\%] & 82.9 & 76.0 & 89.0 & $\mathrm{p}<0.05$ between groups $\mathrm{C}$ and $\mathrm{B}$ \\
\hline Insulin therapy [\%] & 68.3 & 55.0 & 29.0 & $p<0.05$ between groups $C$ and $A$ and $B$ \\
\hline
\end{tabular}

Table IIA. Distribution of FTO polymorphism rs9939609 in the study groups

Tabela IIA. Rozklad polimorfizmu rs9939609 genu FTO w badanych grupach

\begin{tabular}{llll}
\hline & AA & AT & TT \\
\hline Diabetes diagnosis at $<40$ years & $20(24.30 \%)$ & $34(41.46 \%)$ & $28(34.15 \%)$ \\
\hline Diabetes diagnosis at $40-60$ years & $24(24 \%)$ & $52(52 \%)$ & $24(24 \%)$ \\
\hline Diabetes diagnosis at $>60$ years & $22(22 \%)$ & $43(43 \%)$ & $35(35 \%)$ \\
\hline
\end{tabular}

Table IIB. Distribution of FTO polymorphism rs1421085 in the study groups

Tabela IIB. Rozktad polimorfizmu rs1421085 genu FTO w badanych grupach

\begin{tabular}{llll}
\hline & CC & CT & TT \\
\hline Diabetes diagnosis at $<40$ years & $21(25.61 \%)$ & $38(46.34 \%)$ & $23(28.05 \%)$ \\
\hline Diabetes diagnosis at $40-60$ years & $28(28 \%)$ & $50(50 \%)$ & $22(22 \%)$ \\
\hline Diabetes diagnosis at $>60$ years & $25(25 \%)$ & $48(48 \%)$ & $27(27 \%)$ \\
\hline
\end{tabular}

Table IIC. Distribution of FTO polymorphism rs9930506 in the study groups

Tabela IIC. Rozktad polimorfizmu rs9930506 genu FTO w badanych grupach

\begin{tabular}{llll}
\hline & AA & AG & GG \\
\hline Diabetes diagnosis at $<40$ years & $28(34.15 \%)$ & $32(39.02 \%)$ & $22(26.83 \%)$ \\
\hline Diabetes diagnosis at $40-60$ years & $21(21 \%)$ & $47(47 \%)$ & $32(32 \%)$ \\
\hline Diabetes diagnosis at $>60$ years & $29(29 \%)$ & $47(47 \%)$ & $24(24 \%)$ \\
\hline
\end{tabular}

and other parameters and distribution of FTO examined polymorphisms (rs9939609, rs1421085, and rs9930506).

Tables III A, B, and C, D, E, F show the results of determination of allele distribution for FTO polymorphisms rs9939609, rs1421085, and rs9930506.

No statistically significant difference was shown between the FTO allele (rs9939609, rs1421085, and rs9930506) distribution between the subjects with diabetes diagnosed at $<40,40-60$, and $>60$ years. We did not find statistically significant difference in the FTO allele (rs9939609, rs1421085, and rs9930506) distribution between the subjects with diabetes diagnosed at $<40,40-60$, and $>60$ years, taken together.

There were no statistically significant relationships between the different analysed parameters and 
Table IIIA. Allele distribution of FTO polymorphism rs9939609 in the study groups

Tabela IIIA. Rozktad alleli z polimorfizmem rs9930506 genu FTO w badanych grupach

\begin{tabular}{lll}
\hline & Allele A (\%) & Allele T (\%) \\
\hline Diabetes diagnosis at $<40$ years & $74(44 \%)$ & $90(56 \%)$ \\
\hline Diabetes diagnosis at $40-60$ years & $100(50 \%)$ & $100(50 \%)$ \\
\hline Diabetes diagnosis at $>60$ years & $87(43.5 \%)$ & $113(56.5 \%)$ \\
\hline
\end{tabular}

Table IIIC. Allele distribution of FTO polymorphism rs9930506 in the study groups

Tabela IIIC. Rozktad alleli z polimorfizmem rs9930506 genu FTO $w$ badanych grupach

\begin{tabular}{lll}
\hline & Allele A (\%) & Allele G (\%) \\
\hline Diabetes diagnosis at $<40$ years & $88(52.4 \%)$ & $76(47.6 \%)$ \\
\hline Diabetes diagnosis at $40-60$ years & $89(44.5 \%)$ & $111(55.5 \%)$ \\
\hline Diabetes diagnosis at $>60$ years & $105(52.5 \%)$ & $95(47.5 \%)$ \\
\hline
\end{tabular}

Table IIIE. Allele distribution of FTO polymorphism rs1421085 in the study groups

Tabela IIIE. Rozktad alleli z polimorfizmem rs1421085 genu FTO $w$ badanych grupach

\begin{tabular}{lll}
\hline & Allele C (\%) & Allele T (\%) \\
\hline Diabetes diagnosis at $<40$ years & $80(47.6 \%)$ & $84(53.25 \%)$ \\
\hline $\begin{array}{l}\text { Diabetes diagnosis at } 40-60 \text { years } \\
\text { and diabetes diagnosis }\end{array}$ & $204(51 \%)$ & $196(49 \%)$ \\
at $>60$ years, together & & \\
\hline
\end{tabular}

distribution of examined FTO alleles (rs9939609, rs1421085, and rs9930506).

\section{Discussion}

The Fat Mass and Obesity (FTO) gene is considered as leading obesity and type 2 diabetes [8]. The FTO rs9939609 minor allele, the risk allele for obesity, increased the risk of type 2 diabetes, this association remaining statistically significant even after adjustment for BMI [9]. Similar results were reported in a Scandinavian population [10]. In contrast, other studies, despite finding a higher type 2 diabetes risk in carriers of the risk-allele for obesity, concluded that this association disappears when adjusting for BMI and diabetes [11].

A CpG site in the first intron of the FTO gene showed small $(3.35 \%$ ) but significant (P 5 0.000021) hypomethylation of cases relative to controls. The effect was independent of the sequence polymorphism in the region and persisted among individuals carrying the sequence-risk alleles. The odds of belonging to the
Table IIIB. Allele distribution of FTO polymorphism rs1421085 in the study groups

Tabela IIIB. Rozkład alleli z polimorfizmem rs1421085 genu FTO w badanych grupach

\begin{tabular}{lll}
\hline & Allele C $(\%)$ & Allele T $(\%)$ \\
\hline Diabetes diagnosis at $<40$ years & $80(47.6 \%)$ & $84(53.25 \%)$ \\
\hline Diabetes diagnosis at $40-60$ years & $106(53 \%)$ & $94(47 \%)$ \\
\hline Diabetes diagnosis at $>60$ years & $98(49 \%)$ & $102(51 \%)$ \\
\hline
\end{tabular}

Table IIID. Allele distribution of FTO polymorphism rs9939609 in the study groups

Tabela IIID. Rozktad alleli z polimorfizmem rs9939609 genu FTO w badanych grupach

\begin{tabular}{lll}
\hline & Allele A (\%) & Allele T (\%) \\
\hline Diabetes diagnosis at $<40$ years & $74(44 \%)$ & $90(56 \%)$ \\
\hline $\begin{array}{l}\text { Diabetes diagnosis at } 40-60 \text { years } \\
\text { and diabetes diagnosis }\end{array}$ & $187(46.25 \%)$ & $213(53.25 \%)$ \\
at $>60$ years, together & & \\
\hline
\end{tabular}

Table IIIF. Allele distribution of FTO polymorphism rs9930506 in the study groups

Tabela IIIF. Rozktad alleli z polimorfizmem rs9930506 genu FTO w badanych grupach

\begin{tabular}{lll}
\hline & Allele A (\%) & Allele G (\%) \\
\hline Diabetes diagnosis at $<40$ years & $88(52.4 \%)$ & $76(47.6 \%)$ \\
\hline $\begin{array}{l}\text { Diabetes diagnosis at 40-60 years } \\
\text { and diabetes diagnosis at }>60\end{array}$ & $194(48.5 \%)$ & $206(51.5 \%)$ \\
years, together & & \\
\hline
\end{tabular}

T2DM group increased by $6.1 \%$ for every $1 \%$ decrease in methylation (OR 51.061, 95\% CI: 1.032-1.090); the odds ratio for decrease of 1 standard deviation of methylation (adjusted to gender) was 1.5856 (95\% CI: 1.2824-1.9606), and the sensitivity (area under the curve $50.638,95 \%$ CI: 0.586-0.690; males 50.675, females 50.609) was better than that of the strongest known sequence variant [6].

In the pathogenesis of diabetes both environmental genetic factors take part. In the studies conducted to date, 75 independent genetic loci have been identified involved in the development of type 2 diabetes [2]. Type 2 diabetes develops at different ages, with some people developing this before the age of 40 years, others between 40-60 years of age, and some at over 60 years old. We asked ourselves whether the FTO polymorphism plays an important role in this process.

To find an answer to the above question, we examined a group of 282 patients with type 2 diabetes, divided into three groups taking into account the age at which they were diagnosed with the disease. Patients were assigned to the following groups: people with diabetes diagnosed at 
$<40$ years of age $(n=82)$, those with diabetes diagnosed at between 40 and 60 years of age $(n=100)$, and patients with diabetes diagnosed at $>60$ years of age $(n=100)$. In all patients, we defined the basic anthropometric parameters analysed and used for treatment. We have shown that there are significant differences between the two groups. These differences are presented in Table I. In addition, we proved that people with previously diagnosed diabetes at the time of the study were younger, diabetes lasted longer with them, and their treatment more often included insulin. The results are no surprise; the age of diagnosis was the inclusion parameter for different groups. More frequent use of insulin in patients with diabetes diagnosed before the age of 40 years was due to the fact that diabetes lasted significantly longer with them. Diabetes mellitus is a progressive disease and it leads to systematic damage to the beta cells, eventually destroying them, which leads to a need for insulin therapy.

In our work, we examined three polymorphisms of the FTO gene. We compared the distribution of these polymorphisms in patients with diabetes and on this basis we have shown that the treatment groups did not differ in a statistically significant way from each other in relation to the distribution of polymorphisms rs9939609, rs1521085, and rs9930506 (Table IIA, 2B, 2C). At the same time, we found no statistically significant difference in the distributions of allele FTO polymorphisms studied between the two groups (Table IIIA, 3B, 3C).

Comparing the group of people with diabetes diagnosed between the ages of 40 and 60 years old and the group in which diabetes was diagnosed at 60 years of age, we also noted significant differences in the distribution of polymorphisms of the FTO gene, as well as alleles of these polymorphisms (Table IIID, 3E, 3F).

In our work we do not have considered, however, whether the FTO gene is involved in the pathogenesis of type 2 diabetes, but only over whether the importance of this gene in the pathogenesis of type 2 diabetes is higher in patients whose diabetes was diagnosed at a younger age ( $<40$ years old) as compared to diabetic patients diagnosed at age $40-60$ years or over 60 years. The survey showed that the studied FTO polymorphisms have no impact on the age at which diabetes develops.

\section{Conclusions}

1. No significant relationships between the different analysed anthropometric and other parameters and distribution of examined FTO polymorphisms (rs9939609, rs1421085, and rs9930506).

2. The age of diabetes was not affect by the tested FTO polymorphisms (rs9939609, rs1421085, and rs9930506).

\section{References}

1. Guariguata L, Whiting DR, Hambleton I, et al. Global estimates of diabetes prevalence for 2013 and projections for 2035. Diabetes Res Clin Pract. 2014; 103(2): 137-149, doi: 10.1016/j.diabres.2013.11.002, indexed in Pubmed: 24630390.

2. KwakSH, Park KS. Recent progress in genetic and epigenetic research on type 2 diabetes. Exp Mol Med. 2016; 48: e220, doi: 10.1038/emm.2016.7, indexed in Pubmed: 26964836.

3. Scott LJ, Mohlke KL, Bonnycastle LL, et al. A Genome-Wide Association Study of Type 2 Diabetes in Finns Detects Multiple Susceptibility Variants. Science. 2007; 316(5829): 1341-1345, doi: 10.1126/ science.1142382.

4. Zeggini E, Weedon MN, Lindgren CM, et al. Wellcome Trust Case Control Consortium (WTCCC). Replication of genome-wide association signals in UK samples reveals risk loci for type 2 diabetes. Science. 2007; 316(5829): 1336-1341, doi: 10.1126/science.1142364, indexed in Pubmed: 17463249

5. Saxena R, Voight BF, Lyssenko V, et al. Diabetes Genetics Initiative of Broad Institute of Harvard and MIT, Lund University, and Novartis Institutes of BioMedical Research. Genome-wide association analysis identifies loci for type 2 diabetes and triglyceride levels. Science. 2007; 316(5829): 1331-1336, doi: 10.1126/science.1142358, indexed in Pubmed: 17463246.

6. Toperoff G, Aran D, Kark JD, et al. Genome-wide survey reveals predisposing diabetes type 2-related DNA methylation variations in human peripheral blood. Hum Mol Genet. 2012; 21(2): 371-383, doi: 10.1093/ hmg/ddr472, indexed in Pubmed: 21994764.

7. Rodriguez S, Gaunt TR, Day INM. Hardy-Weinberg equilibrium testing of biological ascertainment for Mendelian randomization studies. Am J Epidemiol. 2009; 169(4): 505-514, doi: 10.1093/aje/kwn359, indexed in Pubmed: 19126586.

8. Ortega-Azorín C, Sorlí JV, Asensio EM, et al. Associations of the FTO rs9939609 and the MC4R rs17782313 polymorphisms with type 2 diabetes are modulated by diet, being higher when adherence to the Mediterranean diet pattern is low. Cardiovasc Diabetol. 2012; 11: 137, doi: 10.1186/1475-2840-11-137, indexed in Pubmed: 23130628.

9. Cecil J, Dalton M, Finlayson G, et al. Obesity and eating behaviour in children and adolescents: contribution of common gene polymorphisms. Int Rev Psychiatry. 2012; 24(3): 200-210, doi: 10.3109/09540261.2012.685056, indexed in Pubmed: 22724641.

10. Hertel JK, Johansson S, Sonestedt E, et al. FTO, Type 2 Diabetes, and Weight Gain Throughout Adult Life: A Meta-Analysis of 41,504 Subjects From the Scandinavian HUNT, MDC, and MPP Studies. Diabetes. 2011; 60(5): 1637-1644, doi: 10.2337/db10-1340.

11. Thomsen M, Dahl M, Tybjærg-Hansen A, et al. $\beta 2$-adrenergic receptor Thr164Ile polymorphism, obesity, and diabetes: comparison with FTO, MC4R, and TMEM18 polymorphisms in more than 64,000 individuals. J Clin Endocrinol Metab. 2012; 97(6): E1074-E1079, doi: 10.1210/jc.20113282, indexed in Pubmed: 22466342. 